\title{
Pengaruh Jintan Hitam (Nigella Sativa) pada Konversi Sputum dan IFN- $\gamma$ Penderita Tuberkulosis Paru yang Mendapat OAT Kategori I pada Akhir Minggu Kedua Fase Intensif
}

\author{
Ahmad Nurdin, Helmia Hasan \\ Departemen Pulmonologi dan Ilmu Kedokteran Respirasi, Fakultas Kedokteran Universitas Airlangga/RSUD Dr. Soetomo
}

\begin{abstract}
Background. Primary resistance is the resistance that occurs in patients who have never received treatment OAT or had ever received treatment OAT is less than 1 month. The incidence of primary MDR in Central Java in 2006 2.07\%. Extrapulmonary TB about 15-20\% of all cases of TB, and TB lymphadenitis is the highest form (35\% of all extrapulmonary TB). Patients with decreased immune systems (SLE) can increase the incidence of TB. Research in Spain get 6x higher TB incidence in patients with SLE. Case. We present the case of 19 year old woman SLE who received treatment for 11 months whose came with shortness of breath and chronic cough since 2 month prior to admission. In physical examination we found right and left submandibula lymphonodi enlargement as solid, slightly mobile nodule with diameter $3 \mathrm{~cm}$. Chest $X$ ray showed lung inflammation which suspicion of specific process and minimal left pleural effusion, and concluded as pulmonary TB. FNAB confirmed lymphadenitis TB with granulomatous inflammation. One of AFB result is positive and Gene Xpert is M.tb positive with rifampicin resistant that make this patient categorized as primary MDR TB with lymphadenitis TB. This patient received Pirazinamid 1500 mg, Ethambutol 800 mg, Kanamicin 750 mg, Levofloxacin 750 mg, Ethionamide 500 mg, Cicloserin $500 \mathrm{mg}$, and B6 $100 \mathrm{mg}$. Conclusion. MDR TB in general occur in patients with a history of OAT previous TB (MDR TB secondary). Primary MDR TB with lymphadenitis tb is a rare case, but can occur on the condition that decreases the immune system, one of SLE. This involves multiple immune disorders caused by the use of long-term immunosuppressive therapy.
\end{abstract}

Key words: primary resistance, lymphadenitis TB, SLE

Correspondence: Ahmad Nurdin, Departemen Pulmonologi dan Ilmu Kedokteran Respirasi, Fakultas Kedokteran Universitas Airlangga/ RSUD Dr. Soetomo. J1. Mayjen. Prof. Dr. Moestopo 6-8 Surabaya 60286. E-mail: ahmad.nurdin@ gmail.com

\section{PENDAHULUAN}

Tuberkulosis (TB) merupakan masalah kesehatan masyarakat yang penting di dunia saat ini. Diperkirakan sekitar sepertiga penduduk dunia telah terinfeksi oleh kuman Micobakterium tuberculosis (M.tb). Pada tahun 1992, World Health Organization (WHO) telah mencanangkan TB sebagai Global Emergency. Dari hasil data WHO tahun 2012, Indonesia menempati peringkat keempat negara di dunia dengan jumlah 0,4-0,5 juta penderita tuberkulosis setelah India (2-2,5 juta penderita), Cina (0,9-1,1 juta penderita) dan Afrika Selatan (0,4-0,6 juta penderita). ${ }^{1,2}$

TB Paru BTA positif adalah bentuk TB yang infeksius dan penyebab utama penyebaran penyakit. Penderita yang tidak diobati akan menularkan kepada 10-15 orang lain tiap tahun. Penularan ini tergantung dari bacillary load, adanya kontak dengan pasien dan lamanya waktu pengobatan OAT. ${ }^{3}$ Beberapa peneliti mendapatkan penurunan jumlah kuman BTA yang cepat setelah mendapat terapi OAT selama lebih kurang 2 minggu. ${ }^{4}$ Mitchison dkk melaporkan bahwa $80-85 \%$ penderita TB paru menjadi tidak infeksius setelah sekitar 2 minggu pengobatan OAT, sedangkan Wang dkk memperkirakan lebih dari $50 \%$ penderita tuberkulosis masih infeksius setelah 2 minggu pengobatan. ${ }^{5,6}$ Hutapea T dikutip dari Chrisdiono di BP4 tahun 1998 melaporkan tingkat konversi sputum dengan kombinasi 4 macam obat setelah pengobatan 2 bulan sebesar 68\%, sedangkan penelitian Indah Nur di Poli Paru RSUD dr Soetomo tahun 2000 sebesar $64 \% .^{7}$

Micobacterium tuberculosis merupakan bakteri fakultatif intraseluler. Dalam menghadapi mikroorganisme intraseluler, respons imun yang terjadi adalah respons 
imun seluler. Sel T helper-1 (Th1) sangat berperan pada sistem pertahanan tubuh terutama dalam menghadapi infeksi bakteri intraselular. Salah satu ciri mikroorganisme intraseluler adalah kemampuannya untuk dapat hidup bahkan berkembangbiak dalam fagosit. ${ }^{8}$ Pada sistem imun seluler, sel $\mathrm{T}$ yang terstimulasi oleh antigen akan mengaktivasi makrofag untuk menghancurkan mikroorganisme yang difagosit. ${ }^{8}$ Makrofag melaksanakan sebagian besar fungsi efektornya hanya setelah sel itu diaktivasi oleh macrophage activating factors (MAF). Aktivasi tersebut dapat mengkonversi oksigen molekul menjadi reactive oxygen intermediate (ROI) dan memproduksi Nitric Oxide (NO) yang berperan penting sebagai mediator sitotoksik terhadap sel tumor dan mikroorganisme intraseluler. , $^{8,10}$

Micobacterium tuberculosis dapat menginduksi produksi ROS (Reactive Oxygen Species). Hal ini akan memberikan kontribusi terhadap kondisi immunosupresi, terutama pada mereka dengan gangguan kapasitas antioksidan. Selain itu kondisi malnutrisi yang umumnya terdapat pada pasien dengan TB dapat menambah gangguan kapasitas antioksidan. Pasien TB tidak dapat menghasilkan jumlah antioksidan yang cukup untuk mengatasi stres oksidatif yang meningkat di dalamnya. Oleh karena itu, dianjurkan pemberian suplemen antioksidan untuk melindungi mereka dari serangan radikal bebas.., 10

Penggunaan imunomodulator menarik perhatian untuk menbantu mengatasi TB, terutama karena peningkatan persentase penderita yang resisten terhadap OAT. Imunomodulator diharapkan dapat digunakan untuk memperbaiki atau membangun kembali sistem imun yang kurang sempurna atau mengalami disfungsi. ${ }^{11}$ Nigella sativa atau yang dikenal sebagai jintan hitam telah lama digunakan untuk meningkatkan kesehatan dan melawan penyakit. Kandungan kimia Nigella sativa terdiri atas bermacam zat tapi yang telah diketahui memiliki peran secara farmakologis adalah thymoquinone dan asam linoleat. ${ }^{12}$ El-Kadi dan Kandil membuktikan bahwa Nigella sativa dapat meningkatkan populasi sel T helper (Th) serta rasio sel Thelper terhadap sel $\mathrm{T}$ suppressor (Ts) yang rendah. ${ }^{13}$ Nigella sativa juga dilaporkan dapat meningkatkan produksi IL-3 dan IL-1ß. ${ }^{15}$ Penelitian yang dilakukan oleh Randhawa secara in vitro melaporkan bahwa thymoquinone memiliki aktifitas yang layak sebagai anti tuberkulosis dengan MIC 20 mikrogram $/ \mathrm{ml}^{16}$ Berbagai penelitian yang telah membuktikan efek Nigella sativa dalam menstimulasi sitokin MAF mengindikasikan potensi Nigella sativa dalam meningkatkan fungsi makrofag yang berperan dalam sistem imun seluler. ${ }^{17}$

Berdasarkan data-data tersebut, maka pada penelitian ini akan dilakukan pemberian jintan hitam (Nigella sativa) sebagai suplemen pada penderita TB Paru guna mengoptimalkan hasil pengobatan. Penambahan jintan hitam sebagai antioksidan, antimikroba dan imunomodulator alami pada penderita TB Paru BTA positif diharapkan dapat membantu terjadinya konversi sputum dan meningkatkan kadar IFN- $\gamma$ sehingga dapat mempercepat respons kesembuhan dan mengurangi risiko penularan terhadap orang lain.

\section{METODE}

Penelitian ini merupakan penelitian eksperimental dengan desain penelitian Randomized Controlled Trial Pre Test-Post Test Control Group Design yang teknik dalam pengambilan sampel yaitu dengan cara random sampling, yakni pemilihan secara acak dari sampel yang telah ada, jenisnya adalah secara acak sederhana (simple random sampling). Sampel penelitiannya adalah pasien TB Paru BTA positif kasus baru di ruang rawat jalan maupun rawat inap RSUD Dr. Soetomo Surabaya yang memenuhi kriteria inklusi. Kriteria inklusi adalah pasien TB Paru BTA positif kasus baru, bersedia menjadi subyek penelitian dengan menandatangani surat persetujuan, berjenis kelamin lakilaki dan perempuan, usia diatas 15 tahun, sedangkan kriteria eksklusi adalah penderita dengan HIV/AIDS, IMT sangat kurus $\left(<17 \mathrm{~kg} / \mathrm{m}^{2}\right)$, penderita dengan DM, penderita hamil dan kondisi imunosupresi (penyakit autoimun, keganasan, terapi steroid dosis tinggi).

Instrumen yang digunakan adalah Penelitian ini menggunakan spuit $10 \mathrm{cc}$, elastic band, tabung vaculab, pot sputum, ELISA kit IFN- $\gamma$, Jintan hitam kapsul minyak dosis $2500 \mathrm{mg} /$ hari, lembar pengumpul data, alat timbang berat badan dan tinggi badan. Sistem kerja penelitian yang pertama adalah; masukkan jarum ke dalam vena, sambungkan jarum dengan tube dan diisi dengan darah sanple, lepaskan elastic band dari lengan, letakkan kapas pada bekas suntikan, kedua; pemeriksaan kadar IFN- $\gamma$. Kadar IFN- $\gamma$ diukur dengan menggunakan ELISA (Enzymlinked immunosorbent assay) yang dinyatakan dalam satuan $\mathrm{pg} / \mathrm{ml}$ dan yang ketiga adalah; pemeriksaan hapusan sputum BTA dilakukan pada awal penegakan diagnosis dan minggu kedua fase intensif.

Pasien diminta membatukkan sputum secara spontan ke dalam 3 pot sputum. Bila penderita tidak mampu membatukkan akan dilakukan induksi sputum. Sputum yang diambil untuk pemeriksaan adalah sewaktu, pagi hari dan sewaktu. Sputum dari batuk spontan diberi label nama, umur, nomer register, tanggal pengambilan spesimen lalu dikirim ke Bagian Mikrobiologi untuk dilakukan pemeriksaan pengecatan sputum dengan metode Ziehl Nielsen. Hasil pengecatan Ziehl Nielsen dibaca dengan skala IUALTD.

Analisis data menggunakan SPSS 15.0 untuk membuktikan pengaruh pemberian jintan hitam (Nigella sativa) terhadap konversi sputum BTA dan peningkatan kadar IFN- $\gamma$ jika ditambahkan pada terapi OAT standar. Analisis yang digunakan untuk menguji hipotesis dilakukan uji t-berpasangan (paired T-test). 


\section{HASIL}

Subyek pada penelitian ini adalah pasien TB Paru BTA positif yang diterapi OAT kategori 1 dan suplemen Jintan Hitam (Nigella sativa) sebagai kelompok perlakuan dan pasien TB Paru BTA positif yang diterapi OAT kategori 1 saja tanpa suplemen Jintan Hitam (Nigella sativa) sebagai kelompok kontrol, dengan jumlah sampel masing-masing sebanyak 28 pasien. Berikut adalah karakteristik pasien TB Paru BTA positif subyek penelitian pada kelompok perlakuan dan kelompok control dapat dilihat pada tabel 1.

Pada kelompok kontrol terdapat 19 (67,9\%) pasien laki-laki dan $9(32,1 \%)$ pasien perempuan. Pada kelompok perlakuan Jintan Hitam terdapat 17 (60,7\%) pasien laki-laki dan $11(39,3 \%)$ pasien perempuan. Hasil chi-square test menunjukkan bahwa tidak ada perbedaan yang bermakna proporsi jenis kelamin antara kelompok kontrol dan kelompok perlakuan Jintan Hitam dengan nilai p sebesar $0,781>0,05$. Rerata usia pada kelompok kontrol adalah 37,9 tahun, dengan umur termuda 19 tahun dan umur tertua 57 tahun, kelompok usia terbanyak adalah 21-30 tahun yaitu $9(32,1 \%)$ pasien. Rerata usia pada kelompok perlakuan Jintan Hitam adalah 33,4 tahun, dengan umur termuda 18 tahun dan umur tertua 57 tahun, kelompok usia terbanyak adalah 21-30 tahun yaitu $10(35,7 \%)$ pasien. Hasil independent $\mathrm{t}$ test menunjukkan bahwa tidak ada perbedaan yang bermakna antara usia kelompok kontrol dan usia kelompok perlakuan Jintan Hitam dengan nilai $p$ sebesar 0,144>0,05. Rerata IMT pada kelompok kontrol adalah 18,7, dengan nilai IMT terendah 17,1 dan nilai IMT tertinggi 21,3, terdapat $14(50 \%)$ pasien termasuk BB kurang dan 14 (50\%) pasien termasuk BB normal. Rerata IMT pada kelompok perlakuan Jintan Hitam

Tabel 1. Karakteristik Pasien TB Paru BTA Positif Subjek Penelitian

\begin{tabular}{|c|c|c|c|}
\hline \multirow[b]{2}{*}{ Karakteristik } & \multicolumn{2}{|c|}{ Kelompok } & \multirow[b]{2}{*}{ Nilai p } \\
\hline & Kontrol & $\begin{array}{c}\text { Perlakuan } \\
\text { Jintan Hitam }\end{array}$ & \\
\hline \multicolumn{4}{|l|}{ Jenis Kelamin } \\
\hline Laki-laki & $19(67,9 \%)$ & $17(60,7 \%)$ & 0,781 \\
\hline Perempuan & $9(32,1 \%)$ & $11(39,3 \%)$ & \\
\hline Usia $($ mean $\pm \mathrm{SD})$ & $37,9 \pm 11,8$ & $33,4 \pm 10,6$ & 0,144 \\
\hline 16-20 tahun & $1(3,6 \%)$ & $2(7,1 \%)$ & \\
\hline 21-30 tahun & $9(32,1 \%)$ & $10(35,7 \%)$ & \\
\hline 31-40 tahun & $6(21,4 \%)$ & $9(32,1 \%)$ & \\
\hline 41-50 tahun & $6(21,4 \%)$ & $4(14,3 \%)$ & \\
\hline 51-60 tahun & $6(21,4 \%)$ & $3(10,7 \%)$ & \\
\hline $\mathrm{IMT}($ mean $\pm \mathrm{SD})$ & $18,7 \pm 1,2$ & $18,6 \pm 1,1$ & 0,643 \\
\hline BB kurang & $14(50,0 \%)$ & $15(53,6 \%)$ & \\
\hline BB normal & $14(50,0 \%)$ & $13(46,4 \%)$ & \\
\hline Kelebihan BB & $0(0,0 \%)$ & $0(0,0 \%)$ & \\
\hline
\end{tabular}

adalah 18,6, dengan nilai IMT terendah 17,1 dan nilai IMT tertinggi 21,2, terdapat $15(53,6 \%)$ pasien termasuk BB kurang dan $13(46,4 \%)$ pasien termasuk BB normal. Hasil independent $t$ test menunjukkan bahwa tidak ada perbedaan yang bermakna antara IMT kelompok kontrol dan IMT kelompok perlakuan Jintan Hitam dengan nilai p sebesar 0,643>0,05.

Berdasarkan hasil uji normalitas data variabel penelitian dengan kolmogorov smirnov test (lihat tabel 2) didapatkan semua data variabel penelitian berdistribusi normal dengan nilai $\mathrm{p}>0,05$. Berdasarkan perbandingan kadar IFN- $\gamma$ antara sebelum terapi dan setelah terapi pada kelompok kontrol dan kelompok perlakuan Jintan Hitam (lihat tabel 3) disimpulkan bahwa pada kelompok kontrol rerata kadar IFN- $\gamma$ sebelum terapi adalah $54,7 \mathrm{pg} / \mathrm{mL}$, dengan nilai terendah $34,3 \mathrm{pg} / \mathrm{mL}$ dan nilai tertinggi 87,1 $\mathrm{pg} / \mathrm{mL}$. Sedangkan rerata kadar IFN- $\gamma$ setelah terapi adalah $57,3 \mathrm{pg} / \mathrm{mL}$, dengan nilai terendah $34 \mathrm{pg} / \mathrm{mL}$ dan nilai tertinggi 87,9 pg/mL. Hasil paired t test pada kelompok kontrol menunjukkan bahwa ada perbedaan yang bermakna antara kadar IFN- $\gamma$ sebelum terapi dan setelah terapi dengan nilai p sebesar $0,015<0,05$. Disimpulkan pasien TB Paru BTA positif yang diterapi OAT kategori 1 tanpa pemberian suplemen Jintan Hitam (Nigella sativa), setelah dilakukan terapi mempunyai kadar IFN- $\gamma$ yang lebih tinggi.

Pada kelompok perlakuan Jintan Hitam rerata kadar IFN- $\gamma$ sebelum terapi adalah $56,7 \mathrm{pg} / \mathrm{mL}$, dengan nilai terendah 23,8 $\mathrm{pg} / \mathrm{mL}$ dan nilai tertinggi $92,6 \mathrm{pg} / \mathrm{mL}$. Sedangkan rerata kadar IFN- $\gamma$ setelah terapi adalah $65,7 \mathrm{pg} / \mathrm{mL}$, dengan nilai terendah $37,5 \mathrm{pg} / \mathrm{mL}$ dan nilai tertinggi 99,9 pg/mL. Hasil paired t test pada kelompok perlakuan menunjukkan bahwa ada perbedaan yang bermakna antara kadar IFN- $\gamma$ sebelum terapi dan setelah terapi dengan nilai p sebesar 0,000 < 0,05. Disimpulkan pasien TB Paru BTA positif yang diterapi OAT kategori 1 dengan pemberian suplemen Jintan Hitam (Nigella sativa), setelah dilakukan terapi mempunyai kadar IFN- $\gamma$ yang lebih tinggi.

Tabel 2. Kolmogorov Smirnov Test

\begin{tabular}{lcc}
\hline \multirow{1}{*}{ Variabel } & \multicolumn{2}{c}{ Nilai p } \\
\cline { 2 - 3 } & Kontrol & $\begin{array}{c}\text { Perlakuan Jintan } \\
\text { Hitam }\end{array}$ \\
\hline Usia (tahun) & 0,877 & 0,814 \\
IMT & 0,618 & 0,941 \\
Kadar IFN- $\gamma$ Sebelum Terapi & 0,289 & 0,530 \\
$\quad(\mathrm{pg} / \mathrm{mL})$ & & 0,888 \\
$\begin{array}{l}\text { Kadar IFN- } \gamma \text { Setelah Terapi } \\
(\mathrm{pg} / \mathrm{mL})\end{array}$ & 0,507 & 0,126 \\
$\begin{array}{l}\text { Perubahan Kadar IFN- } \gamma \text { (pg/ } \\
\mathrm{mL})\end{array}$ & 0,374 & \\
\hline
\end{tabular}


Tabel 3. Perbandingan kadar IFN- $\gamma$ antara sebelum terapi dan setelah terapi

\begin{tabular}{lccc}
\hline \multirow{2}{*}{ Kadar IFN- $\boldsymbol{\gamma}(\mathbf{p g} / \mathbf{m L})$} & \multicolumn{2}{c}{ Kelompok } \\
\cline { 2 - 4 } & & Kontrol & \multicolumn{2}{c}{ Perlakuan Jintan Hitam } \\
\cline { 2 - 4 } & mean \pm SD & Nilai p & mean \pm SD \\
\hline Sebelum Terapi & $54,7 \pm 15,2$ & 0,015 & $56,7 \pm 18,3$ \\
Setelah Terapi & $57,3 \pm 15,9$ & & $65,7 \pm 17,4$ \\
\hline
\end{tabular}

Tabel 4. Perbandingan sputum BTA sebelum dan setelah terapi pada kelompok kontrol dan kelompok perlakuan Jintan Hitam

\begin{tabular}{lrrrrrc}
\hline \multirow{2}{*}{ Sputum BTA } & \multicolumn{5}{c}{ Kelompok } \\
\cline { 2 - 6 } & \multicolumn{3}{c}{ Kontrol } & \multicolumn{3}{c}{ Perlakuan Jintan Hitam } \\
\cline { 2 - 6 } & Pesitif & Negatif & Nilai p & Positif & Negatif & Nilai p \\
Sebelum Terapi & $28(100,0 \%)$ & $0(0,0 \%)$ & 0,000 & $28(100,0 \%)$ & $0(0,0 \%)$ & 0,000 \\
Setelah Terapi & $9(32,1 \%)$ & $19(67,9 \%)$ & & $3(10,7 \%)$ & $25(89,3 \%)$ & \\
\hline
\end{tabular}

Tabel 5. Perbandingan perubahan kadar IFN- $\gamma$ antara kelompok kontrol dan kelompok perlakuan Jintan Hitam

\begin{tabular}{lcc}
\hline \multicolumn{1}{c}{ Kelompok } & \multicolumn{2}{c}{ Perubahan Kadar $\mathrm{IFN}-\gamma(\mathrm{pg} / \mathrm{mL})$} \\
\cline { 2 - 3 } & mean $\pm \mathrm{SD}$ & Nilai $\mathrm{p}$ \\
\hline Kontrol & $2,5 \pm 5,1$ & 0,000 \\
Perlakuan Jintan Hitam & $9,0 \pm 7,5$ & \\
\hline
\end{tabular}

Tabel 6. Perbandingan perubahan sputum BTA antara kelompok kontrol dan kelompok perlakuan Jintan Hitam

\begin{tabular}{lccc}
\hline \multicolumn{1}{c}{ Sputum BTA } & \multicolumn{3}{c}{ Perubahan Sputum BTA } \\
\cline { 2 - 4 } & Tidak Terjadi Konversi Sputum & Terjadi Konversi Sputum & Nilai p \\
\hline Kontrol & $9(32,1 \%)$ & $19(67,9 \%)$ & 0,101 \\
Perlakuan Jintan Hitam & $3(10,7 \%)$ & $25(89,3 \%)$ & \\
\hline
\end{tabular}

Tabel 7. Hubungan perubahan kadar IFN- $\gamma$ dengan jenis kelamin, usia dan IMT

\begin{tabular}{|c|c|c|c|}
\hline \multirow{2}{*}{\multicolumn{2}{|c|}{ Perubahan Kadar IFN- $\gamma$}} & \multicolumn{2}{|c|}{ Nilai p } \\
\hline & & Kontrol & Perlakuan Jintan Hitam \\
\hline Chi-Square Test & Jenis Kelamin & 1,000 & 1,000 \\
\hline \multirow[t]{2}{*}{ Pearson Correlation } & Usia & 0,004 & 0,463 \\
\hline & IMT & 0,881 & 0,745 \\
\hline
\end{tabular}

Berdasarkan perbandingan sputum BTA sebelum dan setelah terapi pada kelompok kontrol dan kelompok perlakuan Jintan Hitam (lihat tabel 4) didapatkan bahwa pada kelompok kontrol, sebelum dilakukan terapi semuanya yaitu $28(100 \%)$ pasien memiliki sputum BTA positif. Setelah dilakukan terapi terdapat $9(32,1 \%)$ pasien yang memiliki suptum BTA positif, sedangkan 19 (67,9\%) memiliki suptum BTA negatif. Hasil menemar test pada kelompok kontrol menunjukkan bahwa ada perbedaan yang bermakna antara sputum BTA sebelum terapi dan setelah terapi dengan nilai $\mathrm{p}$ sebesar $0,000<0,05$. Disimpulkan pasien TB Paru BTA positif yang diterapi OAT kategori 1 tanpa pemberian suplemen Jintan Hitam (Nigella sativa), setelah dilakukan terapi lebih banyak yang lebih banyak terjadi konversi sputum.

Pada kelompok perlakuan Jintan Hitam, sebelum dilakukan terapi semuanya yaitu $28(100 \%)$ pasien memiliki sputum BTA positif. Setelah dilakukan terapi terdapat $3(10,7 \%)$ pasien yang memiliki suptum BTA positif, sedangkan $25(89,3 \%)$ memiliki suptum BTA negatif. Hasil monemar test pada kelompok perlakuan menunjukkan bahwa ada perbedaan yang bermakna antara sputum BTA sebelum terapi dan sesudah terapi dengan nilai $\mathrm{p}$ sebesar $0,000<0,05$. Disimpulkan pasien TB Paru BTA positif yang diterapi OAT kategori 1 dengan pemberian suplemen Jintan Hitam (Nigella sativa), setelah dilakukan terapi lebih banyak terjadi konversi sputum.

Sedangkan berdasarkan tabel 5 bahwa rerata perubahan kadar IFN- $\gamma$ pada kelompok kontrol sebesar 2,5 pg/mL, dengan perubahan terkecil $-5,5 \mathrm{pg} / \mathrm{mL}$ dan perubahan terbesar $18,1 \mathrm{pg} / \mathrm{mL}$ dan rerata perubahan kadar IFN- $\gamma$ pada kelompok perlakuan Jintan Hitam sebesar 9 pg/mL, dengan perubahan terkecil 1,6 $\mathrm{pg} / \mathrm{mL}$ dan perubahan terbesar 36,7 $\mathrm{pg} / \mathrm{mL}$. Hasil independent $\mathrm{t}$ test menunjukkan bahwa ada 
perbedaan yang bermakna antara perubahan kadar IFN- $\gamma$ kelompok kontrol dan perubahan kadar IFN- $\gamma$ kelompok perlakuan Jintan Hitam dengan nilai p sebesar $0,000<0,05$. Disimpulkan pasien TB Paru BTA positif yang diterapi OAT kategori 1 dengan pemberian suplemen Jintan Hitam (Nigella sativa) mempunyai perubahan kadar IFN- $\gamma$ yang lebih tinggi daripada pasien TB Paru BTA positif yang diterapi OAT kategori 1 tanpa pemberian suplemen Jintan Hitam (Nigella sativa).

Berdasarkan perbandingan perubahan sputum BTA antara kelompok kontrol dan kelompok perlakuan Jintan Hitam (lihat tabel 6) disimpulkan bahwa pada kelompok kontrol terdapat $19(67,9 \%)$ pasien yang mengalami konversi sputum BTA dari positif menjadi negatif. Sedangkan pada kelompok perlakuan Jintan Hitam terdapat $25(89,3 \%)$ pasien yang mengalami konversi sputum BTA dari positif menjadi negatif. Hasil chi-square test menunjukkan bahwa tidak ada perbedaan yang bermakna antara perubahan sputum BTA kelompok kontrol dan perubahan sputum BTA kelompok perlakuan Jintan Hitam dengan nilai p sebesar 0,101 >0,05. Disimpulkan pasien TB Paru BTA positif yang diterapi OAT kategori 1 dengan pemberian suplemen Jintan Hitam (Nigella sativa) mempunyai perubahan sputum BTA yang tidak berbeda nyata dengan pasien TB Paru BTA positif yang diterapi OAT kategori 1 tanpa pemberian suplemen Jintan Hitam (Nigella sativa).

Berdasarkan hasil chi-square test dan pearson correlation antara perubahan kadar IFN- $\gamma$ dengan jenis kelamin, usia dan IMT pasien TB Paru BTA positif subyek penelitian dapat dilihat pada tabel 7 dengan hasil chi-square test antara perubahan kadar IFN- $\gamma$ dengan jenis kelamin pada kelompok kontrol maupun pada kelompok perlakuan Jintan Hitam menyimpulkan bahwa tidak ada hubungan yang bermakna antara perubahan kadar IFN- $\gamma$ dengan jenis kelamin dengan nilai $\mathrm{p}>0,05$. Hal ini berarti jenis kelamin tidak mempengaruhi perubahan kadar IFN- $\gamma$ pasien TB Paru BTA positif baik pada kelompok kontrol maupun pada kelompok perlakuan Jintan Hitam.

Sedangkan hasil pearson correlation antara perubahan kadar IFN- $\gamma$ dengan usia pada kelompok kontrol menyimpulkan bahwa ada hubungan yang bermakna antara perubahan kadar IFN- $\gamma$ dengan usia dengan nilai $\mathrm{p}<0,05$. Hal ini berarti usia bisa mempengaruhi perubahan kadar IFN- $\gamma$ pasien TB Paru BTA positif pada kelompok kontrol, semakin tua usia maka perubahan kadar IFN- $\gamma$ semakin kecil ditunjukkan dengan nilai koefisien sebesar -0,521.

Hasil pearson correlation antara perubahan kadar IFN- $\gamma$ dengan usia pada kelompok perlakuan menyimpulkan bahwa tidak ada hubungan yang bermakna antara perubahan kadar IFN- $\gamma$ dengan usia dengan nilai $\mathrm{p}>0,05$. Hal ini berarti usia tidak mempengaruhi perubahan kadar IFN- $\gamma$ pasien TB Paru BTA positif pada kelompok perlakuan Jintan Hitam.

Hasil pearson correlation antara perubahan kadar IFN- $\gamma$ dengan IMT pada kelompok kontrol maupun pada kelompok perlakuan Jintan Hitam menunjukkan bahwa tidak ada hubungan yang bermakna antara perubahan kadar IFN- $\gamma$ dengan IMT dengan nilai $p>0,05$. Hal ini berarti IMT tidak mempengaruhi perubahan kadar IFN- $\gamma$ pasien TB Paru BTA positif baik pada kelompok kontrol maupun pada kelompok perlakuan Jintan Hitam.

Berdasarkan hasil chi-square test antara perubahan sputum BTA dengan jenis kelamin, usia dan IMT pasien TB Paru BTA positif subyek penelitian pada kelompok kontrol maupun pada kelompok perlakuan Jintan Hitam dapat disimpulkan bahwa tidak ada hubungan yang bermakna antara perubahan sputum BTA dengan jenis kelamin, usia dan IMT dengan nilai $p>0,05$. Hal ini berarti jenis kelamin, usia dan IMT tidak mempengaruhi perubahan sputum BTA pasien TB Paru BTA positif baik pada kelompok kontrol maupun pada kelompok perlakuan Jintan Hitam

\section{PEMBAHASAN}

Penelitian ini bertujuan untuk mengetahui pengaruh pemberian suplemen jintan hitam (Nigella sativa) bersama OAT kategori 1 pada konversi sputum BTA dan peningkatan kadar IFN- $\gamma$ pada penderita tuberkulosis paru BTA positif di Rawat Jalan dan Rawat Inap RSUD Dr. Soetomo pada akhir minggu kedua fase intensif.

Dari analisa data statistik untuk sebaran jenis kelamin dengan menggunakan chi-square test menunjukkan bahwa tidak ada perbedaan yang bermakna proporsi jenis kelamin antara kelompok kontrol dan kelompok perlakuan Jintan Hitam dengan nilai p sebesar 0,781>0,05 sebaran usia dengan menggunakan independent $t$ test menunjukkan bahwa tidak ada perbedaan yang bermakna antara usia kelompok kontrol dan usia kelompok perlakuan Jintan Hitam dengan nilai p sebesar 0,144>0,05 (tabel 1), dengan demikian sampel kedua kelompok tersebut adalah homogen.

Data karakteristik subyek penelitian pada tabel 1 menunjukkan jumlah penderita TB Paru BTA positif terbanyak adalah laki-laki yaitu pada kelompok kontrol sebanyak 19 orang $(67,9 \%)$ dan kelompok perlakuan sebanyak 17 orang $(60,7 \%)$. Untuk kelompok usia terbanyak adalah kelompok usia 21-30 tahun yaitu sebanyak 9 orang $(32,1 \%)$ pada kelompok kontrol dan 10 orang $(35,7 \%)$ pada kelompok perlakuan, hal ini sesuai dengan WHO Global Tuberculosis Report 2012 yaitu rasio laki-laki : perempuan sebesar 1.9. ${ }^{1}$

Hal ini menunjukkan bahwa kelompok usia yang rentan terkena TB adalah kelompok usia produktif dan berjenis kelamin laki-laki yang sebagian besar mempunyai kebiasaan merokok dan lebih banyak beraktifitas di luar rumah sehingga mudah untuk tertular TB. Seorang penderita TB dewasa diperkirakan akan kehilangan rata-rata waktu kerjanya 3-4 bulan sehingga berakibat pada kehilangan pendapatan rumah tangganya yaitu sekitar 20-30\%. Hasil uji normalitas data penelitian dengan kolmogorov smirnov test didapatkan semua data variabel penelitian berdistribusi normal (tabel 2). 
Micobacterium tuberculosis merupakan bakteri fakultatif intraseluler. Dalam menghadapi mikroorganisme intraseluler, respons imun yang terjadi adalah respons imun seluler. Sel T helper-1 (Th1) sangat berperan pada sistem pertahanan tubuh terutama dalam menghadapi infeksi bakteri intraselular. Salah satu sitokin yang diproduksi sel Th1 adalah IFN- $\gamma$ yang berperan penting dalam mengeliminasi bakteri M.tb. Pada penderita TB terjadi depresi dari Th1 yang ditandai dengan rendahnya IFN- $\gamma$. Pada penelitian yang dilakukan oleh Widjaja dkk, didapatkan bahwa pada penderita tuberkulosis paru terjadi penurunan kadar IFN- $\gamma$ yang secara statistik bermakna. Beberapa studi juga memperlihatkan bahwa terjadi penurunan kadar IFN- $\gamma$ pada penderita TB aktif. ${ }^{35}$

Kandungan Thymoquinone yang terdapat pada jintan hitam memiliki aktifitas sebagai imunomodulator yang berfungsi untuk memperbaiki atau membangun kembali sistem imun yang kurang sempurna atau mengalami disfungsi. ${ }^{13}$ Pada penelitian ini didapatkan hasil rerata rerata kadar IFN- $\gamma$ pada kelompok kontrol sebelum terapi adalah $54,7 \mathrm{pg} / \mathrm{mL}$, dengan nilai terendah $34,3 \mathrm{pg} / \mathrm{mL}$ dan nilai tertinggi $87,1 \mathrm{pg} / \mathrm{mL}$. Sedangkan rerata kadar IFN- $\gamma$ setelah terapi adalah $57,3 \mathrm{pg} / \mathrm{mL}$, dengan nilai terendah 34 $\mathrm{pg} / \mathrm{mL}$ dan nilai tertinggi $87,9 \mathrm{pg} / \mathrm{mL}$. Hasil paired t test pada kelompok kontrol menunjukkan bahwa ada perbedaan yang bermakna antara kadar IFN- $\gamma$ sebelum terapi dan setelah terapi dengan nilai $\mathrm{p}$ sebesar $0,015<0,05$. Pada kelompok perlakuan Jintan Hitam rerata kadar IFN- $\gamma$ pre terapi adalah $56,7 \mathrm{pg} / \mathrm{mL}$, dengan nilai terendah 23,8 $\mathrm{pg} / \mathrm{mL}$ dan nilai tertinggi $92,6 \mathrm{pg} / \mathrm{mL}$. Sedangkan rerata kadar IFN- $\gamma$ post terapi adalah $65,7 \mathrm{pg} / \mathrm{mL}$, dengan nilai terendah 37,5 pg/mL dan nilai tertinggi 99,9 pg/mL. Hasil paired t test pada kelompok perlakuan menunjukkan bahwa ada perbedaan yang bermakna antara kadar IFN- $\gamma$ pre terapi dan post terapi dengan nilai $\mathrm{p}$ sebesar $0,000<0,05$. Disimpulkan pasien TB Paru BTA positif yang diterapi OAT kategori 1 dengan pemberian suplemen Jintan Hitam (Nigella sativa), setelah dilakukan terapi mempunyai kadar IFN- $\gamma$ yang lebih tinggi (tabel 3 ).

Faktor-faktor yang mempengaruhi kadar IFN- $\gamma$ yaitu genetik, status gizi, jenis kelamin dan usia penjamu. ${ }^{34}$ Hasil pearson correlation antara perubahan kadar IFN- $\gamma$ dengan IMT pada kelompok kontrol maupun pada kelompok perlakuan Jintan Hitam menunjukkan bahwa tidak ada hubungan yang bermakna antara perubahan kadar IFN- $\gamma$ dengan IMT dengan nilai $\mathrm{p}>0,05$. Pada penelitian ini IMT tidak mempengaruhi perubahan kadar IFN- $\gamma$ pasien TB Paru BTA positif baik pada kelompok kontrol maupun pada kelompok perlakuan Jintan Hitam.

Hasil chi-square test antara perubahan sputum BTA dengan jenis kelamin, usia dan IMT pada kelompok kontrol maupun pada kelompok perlakuan Jintan Hitam menyimpulkan bahwa tidak ada hubungan yang bermakna antara perubahan sputum BTA dengan jenis kelamin, usia dan IMT dengan nilai $\mathrm{p}>0,05$. Hal ini berarti jenis kelamin, usia dan IMT tidak mempengaruhi perubahan sputum BTA pasien TB Paru BTA positif baik pada kelompok kontrol maupun pada kelompok perlakuan Jintan Hitam. Hasil ini sesuai dengan penelitian multivarian terhadap penderita tuberkulosis paru yang dilakukan oleh Maderuelo et al., yang menyimpulkan bahwa kadar IFN- $\gamma$ tidak mutlak dipengaruhi oleh jenis kelamin. ${ }^{43}$

Usia turut berpengaruh terhadap respons imun. Vasto et al., melakukan penelitian mengenai hubungan usia dengan imunitas dan menyatakan bahwa pada usia yang lebih tua terjadi penurunan sistem imun. Jumlah sel T relatif tetap namun fungsinya menurun seiring bertambahnya usia. Penurunan sel $\mathrm{T}$ disebabkan oleh adanya perubahan pada lipid membran sel yang menyebabkan lambatnya proses penghantaran sinyal pada sel T CD $4 .{ }^{44}$ Pada penelitian ini di dapatkan pada kelompok kontrol ada hubungan yang bermakna antara perubahan kadar IFN- $\gamma$ dengan usia dengan nilai $\mathrm{p}<0,05$. Hal ini berarti usia bisa mempengaruhi perubahan kadar IFN- $\gamma$ pasien TB Paru BTA positif pada kelompok kontrol, semakin tua usia maka perubahan kadar IFN- $\gamma$ semakin kecil ditunjukkan dengan nilai koefisien sebesar -0,521. Sedangkan pada kelompok perlakuan disimpulkan bahwa tidak ada hubungan yang bermakna antara perubahan kadar IFN- $\gamma$ dengan usia dengan nilai $\mathrm{p}>0,05$. Hal ini berarti usia tidak mempengaruhi perubahan kadar IFN- $\gamma$ pasien TB Paru BTA positif pada kelompok perlakuan Jintan Hitam. Hasil penelitian ini lebih sesuai dengan kesimpulan Maderuelo et al., yang mengatakan bahwa kadar IFN- $\gamma$ tidak dipengaruhi oleh usia. ${ }^{43}$

Jintan hitam bekerja menstimulasi sel T CD4 untuk mensekresi IFN- $\gamma$ yang berguna untuk mengaktifkan respons imun seluler. Pemberian jintan hitam terbukti meningkatkan level IFN- $\gamma$ sehingga mengurangi kerusakan paru. Thymoquinone dilaporkan dapat meningkatkan aktifitas sel T CD4 dan IFN- $\gamma$ serta peningkatan fungsi sel NK. ${ }^{13}$

Sputum BTA merupakan satu hal penting yang harus dievaluasi pada penderita tuberkulosis paru BTA positif. Pada penelitian ini didapatkan hasil hapusan sputum BTA yang menurun secara kuantitatif dan kualitatif pada akhir minggu kedua fase intensif. Pada kelompok kontrol, setelah dilakukan terapi terdapat $9(32,1 \%)$ pasien yang memiliki suptum BTA positif ( 2 subyek dari ++ menjadi,+ 6 subyek dari + tetap + dan 2 subyek ++ sebelum dan setelah terapi), sedangkan 19 (67,9\%) terjadi konversi suptum. Hasil monemar test pada kelompok kontrol menunjukkan bahwa ada perbedaan yang bermakna antara sputum BTA sebelum terapi dan setelah terapi dengan nilai $\mathrm{p}$ sebesar $0,000<0,05$. Pada kelompok perlakuan Jintan Hitam, setelah dilakukan terapi terdapat $3(10,7 \%)$ pasien yang memiliki suptum BTA positif (satu subyek +++ menjadi ++ , satu subyek ++ tetap + dan satu subyek + tetap + ), sedangkan $25(89,3 \%)$ terjadi konversi suptum. Hasil mcnemar test pada kelompok perlakuan menunjukkan bahwa ada perbedaan yang bermakna antara sputum BTA sebelum terapi dan sesudah terapi dengan nilai $\mathrm{p}$ sebesar $0,000<0,05$. Disimpulkan pasien TB Paru BTA positif 
yang diterapi OAT kategori 1 dengan pemberian suplemen Jintan Hitam (Nigella sativa), setelah dilakukan terapi lebih banyak terjadi konversi sputum.

Mitchison dkk melaporkan jumlah kuman BTA menurun dengan cepat setelah dimulai pengobatan OAT, 80-85\% penderita tuberkulosis paru menjadi tidak infeksius setelah sekitar 2 minggu pengobatan. ${ }^{5}$ Sedangkan menurut A. van Deun besarnya konversi sputum setelah empat minggu pengobatan sebesar $52 \%$ pada konversi hapusan sputum. ${ }^{28}$ Pada penelitian ini didapatkan tingkat konversi pada akhir minggu kedua fase intensif pada kelompok kontrol sebesar $67,9 \%$ dan kelompok perlakuan sebesar $89,3 \%$. Pada fase intensif kuman mikobakterium terbunuh dengan cepat dalam waktu 2 minggu sehingga penderita yang infeksius menjadi tidak infeksius dan terjadi perbaikan klinis. Hasil hapusan sputum BTA penderita dipengaruhi oleh berbagai hal misalnya kemampuan penderita untuk batuk yang adekuat, volume dahak yang sedikit (jumlah ideal untuk pemeriksaan 5-10 ml), konsistensi sputum (mukoid atau purulen). Konversi sputum BTA sangat dipengaruhi oleh paduan obat yang tepat, dosis yang tepat, keteraturan minum obat, status gizi dan status imun penderita. Tujuan dari penelitian ini adalah untuk mengetahui pengaruh pemberian suplemen jintan hitam (Nigella sativa) bersama OAT kategori 1 pada konversi sputum dan peningkatan kadar IFN- $\gamma$ penderita TB Paru BTA positif.

Rerata perubahan kadar IFN- $\gamma$ pada kelompok kontrol sebesar 2,5 pg/mL, dengan perubahan terkecil $-5,5 \mathrm{pg} /$ $\mathrm{mL}$ dan perubahan terbesar $18,1 \mathrm{pg} / \mathrm{mL}$. Sedangkan rerata perubahan kadar IFN- $\gamma$ pada kelompok perlakuan Jintan Hitam sebesar $9 \mathrm{pg} / \mathrm{mL}$, dengan perubahan terkecil $1,6 \mathrm{pg} / \mathrm{mL}$ dan perubahan terbesar $36,7 \mathrm{pg} / \mathrm{mL}$. Hasil independent $t$ test menunjukkan bahwa ada perbedaan yang bermakna antara perubahan kadar IFN- $\gamma$ kelompok kontrol dan perubahan kadar IFN- $\gamma$ kelompok perlakuan Jintan Hitam dengan nilai $\mathrm{p}$ sebesar $0,000<0,05$. Disimpulkan pasien TB Paru BTA positif yang diterapi OAT kategori 1 dengan pemberian suplemen Jintan Hitam (Nigella sativa) mempunyai perubahan kadar IFN- $\gamma$ yang lebih tinggi daripada pasien TB Paru BTA positif yang diterapi OAT kategori 1 tanpa pemberian suplemen Jintan Hitam (tabel 5). Pada kelompok kontrol terdapat 19 (67,9\%) pasien yang mengalami konversi sputum. Sedangkan pada kelompok perlakuan Jintan Hitam terdapat 25 (89,3\%) pasien yang mengalami konversi sputum.

Hasil penelitian ini menunjang hipotesis bahwa suplemen jintan hitam (Nigella sativa) bersama OAT kategori 1 dapat membantu terjadinya konversi sputum dan meningkatkan kadar IFN- $\gamma$ penderita TB Paru BTA positif. Selama penelitian berlangsung tidak didapatkan efek samping dari suplemen jintan hitam (Nigella sativa) seperti rasa tidak enak pada perut, mual dan konstipasi, akan tetapi pada penelitian ini tidak dilakukan kultur untuk diagnosis dan menyingkirkan kuman MOTT dan tidak pula dilakukan pemeriksaan khusus terhadap faktor-faktor lain yang dapat mempengaruhi kadar IFN- $\gamma$ seperti penyakit autoimun dan keganasan.

\section{KESIMPULAN}

Pemberian suplemen Jintan Hitam (Nigella sativa) bersama OAT kategori 1 secara bermakna dapat meningkatkan kadar IFN- $\gamma$ penderita TB Paru BTA positif pada akhir minggu kedua fase intensif serta dapat meningkatkan konversi sputum penderita TB Paru BTA positif pada akhir minggu kedua fase intensif, dan pada penelitian ini terdapat peningkatan kadar IFN- $\gamma$ dan tingkat konversi yang lebih tinggi pada penderita TB Paru BTA positif yang diberikan suplemen Jintan Hitam (Nigella sativa) bersama OAT kategori 1 dibandingkan yang tidak diberikan suplemen Jintan Hitam (Nigella sativa) pada akhir minggu kedua fase intensif .

\section{DAFTAR PUSTAKA}

1. World Health Organization. Global Tuberculosis Report 2012. Genewa, Swiss.

2. Perhimpunan Dokter Paru Indonesia. Tuberkulosis. Dalam: Tuberkulosis, Pedoman diagnosis dan penatalaksanaan di Indonesia. Balai Penerbit FKUI. Jakarta. 2011; h. 1-64.

3. Pajankar S, Khandekar R, Al Amri M, Al Lawati MR, Factor influencing sputum smear conversion of one and two month of Tuberculosis treatment. Oman Medical Journal 2008: Vol. 23.

4. Soedarsono. Evaluasi terapi tuberkulosis: klinis dan program. Dalam TB Update-II. Simposium Nasional, Lab/SMF Ilmu Penyakit Paru FK Unair/RSUD Dr. Soetomo Surabaya, 2003. 49-68.

5. Mitchison DA. Infectivity of patients with pulmonary tuberculosis during chemotherapy. Eur Respir J. 1990; 3: 385-6.

6. Wang JY, Lee LN, Yu CJ, Chien YJ, Yang PC, Tami Group. Factors influencing time to smears conversion in patients with smear positive pulmonary tuberculosis. Respirol. 2009;14:1012-9.

7. Chrisdiono H. Konversi sputum BTA pada penderita TB Paru kasus baru yang mendapat terapi OAT kategori 1 dan Phyllantus Niruri L. Penelitian karya akhir Bagian Paru UNAIR. 2003.

8. Bhatt K, Salgem P. Host innate immune response to Mycobacterium tuberculosis. J Clin Immunol. 2007; 27 (4): 347-62.

9. Reddy YN, Muthy SV. Role of free radicals and antioxidants in tuberculosis patients. Indian J Tuberc. 2004; 51: 213-18.

10. Mohod K, Dhok A, Kumar S. status of oxidants and antioxidants in pulmonary tuberculosis with varying bacillary load. Journal of Experimental Sciences 2011; 2 (6): 35-7.

11. Djauzi S. Perkembangan obat imunomodulator. Med J Ked 2003; 4 (2): $13-5$.

12. Salem M. L. Immunomodulatory and Therapeutic Properties of The Nigella sativa L. Seed. International Immunopharmacology 2005; 5: 1749-70.

13. ElKadi A, Kandil O. Effect of Nigella sativa (the black seed) on immunity. Proceeding of $4^{\text {th }}$ International Conference on Islamic Medicine, Kuwait. Bull Islamic Med 1986; 4: 344-8.

14. Mansour MA, Ginwai OT, El-Hadiya T, ElKhatib AS. Effects of volantile oil constituents of Nigella sativa on carbon tetrachloridainduced Hepatotoxicity in mice: evidence for antioxidant effect of thymoquinone. Res Commun Mol Pathol Pharmacol. 2001; 110 239-51.

15. Swamy SM, Tan BK. Cytotoxic and imunopotentiating effects of ethanolic extract of Nigella sativa L Seeds. J Ethnopharmacol 2000; 70: 1-7.

16. Randhawa MA. In Vitro Antituberculous activity of thymoquinone, An active principle of Nigella sativa. Journal Ayub Med Coll Abbottabad 2011; 23 (2):78-1.

17. Haq A, Abdullatif M, Lobo PI, Khabar KS, Sheth KV, Al-Sedairy ST. Nigella sativa : Effect on Human Lymphocytes and Polymorphonuclear Leucocyte Phagocytic Activity. Immunopharmacology 1995; 30 (2): 147-155. 
18. Pedoman Diagnosis dan Terapi Bagian/SMF Ilmu Penyakit Paru RSU Dr. Soetomo Surabaya, 2005.

19. Departemen Kesehatan Republik Indonesia (2008), Pedoman Penanggulangan Tuberkulosis, edisi ke-2, Editor Aditama TY dkk, Balai Pustaka, Jakarta, hal. 3-4.

20. Schlossberg D. Tuberculosis and Non tuberculosis Mycobacterium Infection, $5^{\text {nd }}$ ed. McGraw-Hill company, Philadelphia 2006, p.94103.

21. Baratawidjaya KG. Imunologi Dasar. edisi 7, Penerbit FKUI, Jakarta. 2006; hal. 411-7.

22. Abbas AK, Litchtman AH, Puber JS. Immunity to microbes. In: cellular and molecular immunology, $2^{\text {nd }}$ ed. WE Saunders Company Philadelphia. 1994: p. 320-33.

23. Parslow TG, Bainton DF. Innate immunity. In: Parslow TG, Stites DP, Terr AL, Imboden JB, (Eds). Medical Immunology, $10^{\text {th }}$ ed. New York The McGraw-Hill Companies 2001; 19-40.

24. Iseman MD. Immunity and pathogenesis. In: Iseman MD, A clinician's Guide to Tuberculosis. Lippincott Williams and Wilkins. Philadelphia. 2000: p. 63-96.

25. Mattheas L, Steinmuller C, Ulliman GF. Pulmonary macrophage. Eur Respir J. 1994; 7 : 1683-4.

26. Hashmi MA, Ahsan B, Shah SI. Antioxidant capacity and lipid peroxidation product in pulmonary tuberculosis. Al Ameen J Med Sci. 2012; 5 (3): 313-19.

27. Cohen K, Nyska A. Oxidation of biological system : Oxidative stress phenomena. Antioxidants, redox reaction and methods for their quantifications. Toxicologic part. 2002; 30 (6): 620-50.

28. Warren JR, Bhattacharya M, De Almeida KN, Trakas K, Peterson LR. A minimum $5.0 \mathrm{ml}$ of sputum improves the sensitivity of acid fast smears for Mycobacterium tuberculosis. Am J Respir Crit Care Med. 2000 May; 161 (5): 1559-62.

29. Parikh R, Nataraj G, Kanade S, Khatri V, Mehta P. Time to sputum conversion in smear positive pulmonary TB patients on category I DOTS and factors delaying it. Journal Association of Physicians India. 2012: 60: 22-6.

30. A. van Deun. What is the role of mycobacterial culture in diagnosis and case definition? Toman's Tuberculosis. Case detection, treatment, and monitoring-question Second edition. WHO, 2004; p 122-3.

31. Barnes PF, Wizel B. Type 1 cytokines and the pathogenesis of tuberculosis. A, J Respir Crit care Med. 2000; 161: 1773-4.
32. Dannenberg AM, Rook GAW. Pathogenesis of pulmonary tuberculosis: Interplay of tissue-and answers. Second edition. World Health Organization. Geneva. 2004.

33. Toman, K. What is the purpose of the initial intensive phase of twophase treatment In: Toman's Tuberculosis case detection, treatment and monitoring question and aswers. Eddamaging and macrophageactivating immune response, dual mechanism that control bacillary multiplication. In : Bloom BR, editor. ASM Press. Washington. 1994: p. $459-84$.

34. Widjaja JT, Jasaputra DK. Analisis kadar interferon gamma pada penderita tuberkulosis paru dan orang sehat. J Respir Indo. 2010; 30 (2): 119-24.

35. Gilani A, Jabeen Q, Khan M. A Review of medicinal uses and pharmacological Activities of Nigella sativa . Pakistan Journal of Biological Sciences 7 (4): 441-51.

36. Nickavara B, Mojaba F, Javidniab K, Amolia MAR. Chemical composition of the fixed and volatile oils of Nigella sativa L. From Iran. Z. Naturforsch 2003; 58c, 629-1.

37. Farid BA, Aoumeur B, Brahim MY, Farid C. Chemical composition of seed essential oils from Algerian Nigella sativa extracted by microwave and hydrodistillation. Flavour and Fragrance journal 2007; 22 (2): 148-3.

38. Hutapea JR. Inventaris tanaman obat indonesia (III), Badan Penelitian dan Pengembangan Kesehatan, Depkes RI. 1994: 163-5.

39. Randhawa MA. An update on antimicrobial effect of Nigella sativa and experience at King faisal University, Dammam, Saudi Arabia. J Saudi Society Dermatol Dermatologic Surg 2008; 12: 37-44.

40. Farrakh KM, Atoji Y, Shimizu Farrakh KM, Atoji Y, Shimizu Y, Takewaki T. Isulinotropic properties of Nigella sativa oil in streptozotocin plus nicotinamide diabetic hamster. Res Vet Sci 2002; 73: 279-82.

41. El-Gazzar M, El-Mezayen R, Marecki JC, Nicolls MR, Canastar. Anti Inflammatory effect of thymoquinone in mouse model of allergic lung Inflammation. International immunopharmacology 2006; 6: 1135-42.

42. Maderuelo DL, Arnalich F, Serantes R, Gonzales A, Codoceo R, IFN- $\gamma$ and IL-10 gene polymorphisms in pulmonary tuberculosis. Am J Respir Crit Care Med. 2003; 167: 970-5.

43. Vasto S, Malavolta M, Pawelec G. Age and immunity. Immunity \& Ageing. 2006; 3 (2). 1-5. 